https://doi.org/10.18485/iipe_postkovid.2021.ch11

\title{
RAZVOJ POLITIČKOG I EKONOMSKOG SISTEMA EVROPSKE UNIJE NAKON PANDEMIJE KOVID 19
}

\author{
Aleksandar JAZIĆ1 \\ Dragana DABIĆ2
}

\begin{abstract}
Apstrakt: „Bela knjiga o budućnosti Evrope“, koju je Komisija objavila 2017. godine, iznosi pet mogućih puteva napred za Evropsku uniju - od sužavanja fokusa na jedinstveno tržište do produbljivanja i širenja integracije na nove javne politike i oblasti upravljanja. Takođe, uključuje i predlog izgradnje „Evrope u više brzina“, za koji se sada sa velikom sigurnošću može tvrditi da predstavlja kako prošlost i sadašnjost integrativnih procesa tako i njihovu budućnost. „Bela knjiga“ ne uzima u obzir osnovno pitanje uređenja budućeg poretka, a to je kako raspodeliti vlast unutar EU. Ovde Unija nema pet mogućnosti, već dve - komunitarnu (nadnacionalnu) i međuvladinu. Pristup koji bude odabran oblikovaće strukturu Unije i obim njenih aktivnosti. Neko vreme se činilo da je vreme za redizajn Ekonomske i monetarne unije prošlo i da će evrozona morati da funkcioniše sa arhitekturom nasleđenom iz njenih kriznih godina. Novi evropski fond za pomoć članicama koje su najteže pogođene pandemijom virusa Kovid 19 nazvan „Nova generacija EU“, kojim se pod pretpostavkom evropske solidarnosti uvodi ograničena zajednička odgovornost za dug, pokazuje da više nije tako. U literaturi se mogu pronaći različita viđenja daljeg razvoja evropskog projekta ujedinjenja. U predmetnom radu se u okvirima četiri izdvojena scenarija razmatra dugoročni razvoj EU. Tvrdi se da jedino politička odluka može povratiti stabilnost sistema i nanovo uspostaviti jasnu vertikalnu podelu nadležnosti, a time ujedno i obezbediti legitimnost upravljanja evropskim ekonomijama. Politička odluka država članica trebalo bi da se temelji na volji
\end{abstract}

\footnotetext{
${ }^{1}$ Naučni saradnik, Institut za međunarodnu politiku i privredu, Beograd. E-mail: jazic@ diplomacy. bg.ac.rs.

${ }^{2}$ Istraživač saradnik, Institut za međunarodnu politiku i privredu, Beograd. E-mail: ddabic@diplomacy.bg.ac.rs.

Rad je nastao u okviru naučnoistraživačkog projekta „Srbija i izazovi u međunarodnim odnosima 2021. godine“, koji finansira Ministarstvo prosvete, nauke i tehnološkog razvoja Republike Srbije, a realizuje Institut za međunarodnu politiku i privredu tokom 2021. godine.
} 
evropskih građana i može dovesti bilo da izgradnje političke unije sa nadnacionalnom fiskalnom unijom kao njenim sastavnim delom, bilo do odustanka od evra.

Ključne reči: Ekonomska i monetarna unija, evrozona, kriza evra, pandemija, nadnacionalno upravljanje, fiskalna unija, politička unija, Bregzit

\section{Uvod}

„Bela knjiga o budućnosti Evrope“ koju je Komisija objavila 2017. godine, a koja je usmerena na period do 2025. godine, iznosi pet mogućih puteva napred za Evropu - od sužavanja fokusa Evropske unije (EU, Unija) na jedinstveno tržište, do produbljivanja i širenja integracije na nove javne politike i oblasti upravljanja, uključujući i tzv. model „Evrope u više brzina“. ${ }^{3}$ Evropski zvaničnici su predložili desetomesečni rok za raspravu i razmišljanje, koji je trebalo da kulminira na sastanku Evropskog saveta, na kome bi evropski lideri odlučili u kom pravcu će krenuti. Očekivalo se da novi pristup bude saopšten u sklopu evropskih izbora 2019. godine. Kako je napisano u prošlom vremenu, jasno je da se sa ovom ambicioznom strategijom „izjašnjavanja“ nije daleko odmaklo. U međuvremenu, pandemija virusa Kovid 19 stavila je čitav svet na iskušenja, izazivajući zdravstvenu krizu globalnih razmera sa reperkusijama po sve oblasti društvenog organizovanja. Rasprava o poželjnom modelu i dometima integracije čeka bolje vreme. Bez obzira, to nas ne sprečava da iznesemo neka predviđanja u pogledu mogućih puteva transformacije političkog i ekonomskog sistema EU koja su izneta u literaturi evropskih studija.

Složene strukture, još uvek neuobličena (na pola puta između stabilnijih poznatih formi ekonomskog upravljanja) i upitne demokratske legitimnosti, Ekonomska i monetarna unija je polazište za dalja razmatranja unutar različitih disciplina. Način na koji će definitivno biti uobličen evropski sistem upravljanja, kako odnosi između centralnog nivoa i država članica (federalno načelo nasuprot povratku na niže nivoe integracije), tako i odnosi između samih članica (načelo demokratske jednakosti nasuprot nedemokratskog obrasca nadređenosti i podređenosti), presudno će uticati na budućnost evropskog projekta ujedinjenja. ${ }^{4}$

\footnotetext{
${ }^{3}$ European Commission, "White Paper on the Future of Europe: Reflections and scenarios for the EU27 by 2025", COM (2017)2025 of 1 March 2017.

${ }^{4}$ Dragana Dabić, Branimir Gajić, „Evropska bankarska unija kao deo postkriznog sistema upravljanja Ekonomskom i monetarnom unijom“, Evropsko zakonodavstvo, 73-74/2020. str. 77.
} 
Rad će se sastojati iz tri dela. Prvo će biti izloženi zvanični ciljevi koje su evropske institucije predstavile za naredni period. Potom, u drugom delu rada, biće ponuđena četiri široka scenarija dugoročnog razvoja Evropske unije (EU, Unija), da bi napkon, u trećem delu rada, bili razmotreni neki od izazova sa kojima će se Unija suočiti u narednom periodu.

\section{Evropske strategije, planovi i ciljevi za postpandemijsku eru iz vizure evropskoh institucija}

Svake godine tri političke institucije EU - Evropski parlament, Savet i Komisija - raspravljaju i dogovaraju se o zakonodavnim prioritetima EU za narednu godinu, a koji su kao takvi utvrđeni u godišnjoj zajedničkoj deklaraciji. Sadašnji cilj je da dogovor institucija zakonodavne i izvršne vlasti na nivou Unije podstakne oporavak od pandemije Kovid 19, istovremeno koristeći mogućnosti klimatske i digitalne tranzicije.

Istaknuto je da će se u 2021. godini institucije fokusirati na: sprovođenje "evropskog zelenog dogovora", oblikovanje "evropske digitalne decenije", ekonomije koja je „u službi ljudi“, činjenje Evrope „jačom u svetu“, zastupanje „slobodne i bezbedne Evrope", zaštitu i jačanje "naše demokratije“ i "odbranu zajedničkih evropskih vrednosti“. ${ }^{5}$

U dokumentu zvučnog naziva „Vitalna Unija u krhkom svetu“, koji je predstavljen kao radni program Komisije za 2021. godinu, između ostalog navodi se sledeće: „U budućnosti ova godina, takođe može biti zapamćena po velikom ubrzanju promena koje je pokrenula i sjajnoj prilici koju je paradoksalno pružila. Promene u klimi, digitalnim tehnologijama i geopolitici već su duboko uticale na naše društvo i pokrenule našu agendu. Međutim, pandemija je zaoštrila potrebu da Evropa predvodi dvostruku zelenu i digitalnu tranziciju, i učini njena društva i ekonomije otpornijim. Pruža se prilika bez premca za izlazak iz fragilnosti koje je izazvala kriza i da se izađe iz krhkosti krize kreiranjem nove vitalnost za našu Uniju. ${ }^{\prime 6}$

\footnotetext{
${ }^{5}$ Izvor: European Commission, "The joint priorities of the EU institutions for 2021-2024", Internet: https://ec.europa.eu/info/strategy/strategic-planning/joint-priorities-eu-institutions2021-2024_en, 19/06/2021.

${ }^{6}$ Izvod iz: "Communication from the Commission to the European Parliament, the Council, the European Economic and Social Committee and the Committee of the Regions",
} 
Retorika kojom se mnogobrojne krize sa kojima se Unija suočava tokom poslednje decenije i duže instrumentalizuju za nastavak integracionih procesa, postala je nezaobilazni deo agende nadnacionalnih institucija. Razrešenje sadašnjih problema, a koji su delom pogoršani (ne)činjenjem evropskih elita, uvek se traži u „više Evrope“, odnosno političkim pogodbama i institucionalnim rešenjima koja od država članica traže da se dalje odriču autonomije odlučivanja u korist zajedničkog upravljanja.

\section{Masovna vakcinacija kao nastojanje da se pandemija stavi pod kontrolu}

U junu 2020. godine svih 27 članica Unije saglasilo se da se pridruži mehanizmu koji centralnu odgovornosti za kupovinu vakcina daje EU. Međutim, u narednim mesecima se ispostavilo da je EU sporije pregovarala o ugovoru sa proizvođačem vakcina AstraZeneka (engl. AstraZeneca) u odnosu na bivšu članicu Ujedinjeno Kraljevstvo. Kasnije se suočila sa problemima u snabdevanju, zbog kojih je u aprilu ove godine Evropska komisija u ime članica pokrenula tužbu protiv ove kompanije po osnovu kršenja kupoprodajnog ugovora pred nadležnim sudom u Belgiji. U junu je belgijski sud presudio da je AstraZeneka počinila „Ozbiljno kršenje“ ugovora sa EU. I u dogovorima sa drugim proizvođačima vakcina, Komisija se suočila sa manjim problemima u vezi sa proizvodnjom i distribucijom. Predsednica Evropske komisije, Ursula fon der Lajen, priznala je poteškoće EU u procesu nabavki vakcina, rekavši: „Kasnili smo sa odobrenjem. Bili smo previše optimistični kada je u pitanju masovna proizvodnja i možda previše uvereni da će ono što smo naručili zaista biti isporučeno na vreme." ${ }^{\text {"7 }}$

U govorima i predlozima evropskih zvaničnika očitava se nastojanje da zdravstvena kriza izazvana pandemijom virusa Kovid 19 posluži kao katalizator daljih integrativnih procesa u Uniji, pored ostalog, da se izgradi „Evropska zdravstvena unija“. Evropska komisija nastoji da uspostavi Evropsku zdravstvenu uniju, na način da se „sve zemlje EU pripremaju i zajedno reaguju na zdravstvene krize, medicinski materijal je dostupan, pristupačan i inovativan, a zemlje zajedno rade na poboljšanju prevencije, lečenja i nege za bolesti poput raka“. Komisija

Commission Work Programme 2021 - A Union of vitality in a world of fragility, Brussels, 19.10.2020, COM (2020) 690 final, pp. 1-2.

${ }^{7}$ Izvor: BBC News, "Covid: What is happening with the EU vaccine rollout?", Internet: https://www.bbc.com/news/explainers-52380823, 19/06/2021. 
je nedavno pokrenula inicijativu da EU imenuje glavnog evropskog epidemiologa i odgovarajuću upravljačku strukturu do kraja 2021. godine. Takođe se zalaže za uspostavljanje okvira za aktiviranje vanrednog stanja u slučaju pandemije na nivou EU. ${ }^{8}$

\section{Politički razvoj - Konferencija o budućnosti Evrope}

Održavanje nove konferencije o budućnosti Evrope isprva je predložio francuski predsednik Emanuel Makron uoči izbora za Evropski parlament 2019. godine. Trebalo je da počne u maju prošle godine, ali se zastalo zbog institucionalne „prepirke“ oko toga ko će je voditi. Na Dan Evrope, 9. maja 2021. godine, održana je ceremonija otvaranja konferencije u Strazburu, čime je označen početak javnih konsultacija.

Konferencija je pod nadležnošću tri institucije koju predstavljaju predsednik Evropskog parlamenta, predsednik Saveta i predsednik Evropske komisije, delujući kao njeno zajedničko predsedništvo. Zajedničko predsedništvo podržava Izvršni odbor, kojim kopredsedavaju tri institucije a koje predstavlja član Evropskog parlamenta, predstavnica Portugla kao države koja trenutno predsedava Savetom i potpredsednica Evropske komisije zadužena za demokratiju i demografiju. Izvršni odbor redovno podnosi izveštaje zajedničkom predsedništvu. Odgovoran je za donošenje odluka konsenzusom u vezi sa radom Konferencije, njenim procesima i događajima, nadgledanje razvoja Konferencije i pripremu sastanaka plenarnih zasedanja Konferencije, uključujući doprinos građana i njegovo praćenje. Plenarni sastanci Konferencije sastojaće se od predstavnika Evropskog parlamenta, Saveta i Evropske komisije, kao i predstavnika svih nacionalnih parlamenata na ravnopravnoj osnovi i građana. Takođe, biće predstavljeni Komitet regiona i Ekonomski i socijalni savet, socijalni partneri i civilno društvo. Visoki predstavnik Unije za spoljnu politiku i bezbednost biće prisutan kada se razgovara o međunarodnoj ulozi EU. Predstavnici zainteresovanih strana mogu biti pozvani. Izvršnom odboru stavljeno je u nadležnost da sastavi i objavi zaključke sa plenarnih sastanaka. ${ }^{9}$

\footnotetext{
${ }^{8}$ Videti: European Commission, "Emerging stronger from the pandemic: acting on the early lessons learnt”, Internet: https://ec.europa.eu/commission/presscorner/detail/en/ip_21 _2989, 19/06/2021.

${ }^{9}$ Izvor: "The Conference on the Future of Europe", Internet: https://futureu.europa.eu/? locale=en, 19/06/2021.
} 
Specifičnost sadašnje Konferencije o budućnosti Evrope, u odnosu na ranije inicijative koje pamti istorija evropskih integracija, jeste isticanje principa deliberativne demokratije u prvi plan. Naime, na zvaničnoj internet platformi Konferencije navodi se da je reč o „velikom panevropskom demokratskom projektu bliskom građanima i novom javnom forumu za otvornu, inkluzivnu i transparentnu raspravu s građanima o nizu prioriteta i izazova". Pobrojane su sledeće teme kao predmet rasprave: klimatske promene i životna sredina, zdravlje, jača ekonomija, socijalna pravda i radna mesta, EU u svetu, vrednosti i prava, vladavina prava, bezbednost, digitalna transformacija, evropska demokratija, migracije, obrazovanje, kultura, mladi, sport i ostale ideje. ${ }^{10} \mathrm{Ključnu}$ komponentu i novitet koji unosi Konferencija jeste višejezična otvorena digitalna platforma kao svojevrsno mesto za komunikaciju sa građanima -razmenu ideja i slanje predloga. Predlozi će se prikupljati, analizirati, nadgledati i objavljivati tokom trajanja Konferencije. Do proleća 2022. godine očekuje se da će Konferencija doneti zaključke i pružiti smernice o budućnosti Evrope. Očekuje se da konačni dokument sa preporukama koji proizađe iz rada Konferencije bude predstavljen Evropskom savetu na dalju raspravu i primenu. Po svemu sudeći, radi se o do sada moguće najozbiljnijem pokušaju evropskih elita da se približe građanima, ne bi li na taj način umanjili percepciju o deficitu demokratije u Uniji.

\section{Ekonomski oporavak}

Prema poslednjim prognozama Evropske komisije očekuje se da u 2021. godini EU kao celina ostvari rast od $4,2 \%$, dok je procena da će se ekonomija evrozone uvećati za 4,3\%. Oporavku bi trebalo da doprinese i program „Sledeća generacija EU“ (engl. Next Generation EU) dogovoren prošle godine, a koji je od ove godine operativan. Naime, reč je o privremenom planu oporavka u vrednosti od 750 milijardi evra koji se delom sastoji od bespovratnih sredstava, a delom iz zajmova. Ova sredstva ne uplaćuju države članice kako se uobičajeno finansiraju zajednički fondovi, već će se Evropska komisija samostalno zadužiti na finansijskom tržištu. Procena ja da bi zajednički dug Unija trebalo da otplati do 2058. godine. Važno je istaći da Komisija radi otplate duga planira da u periodu od 2021. do 2024. uvede nove digitalne namete, zatim poreze na plastičnu ambalžu, finansijske transakcije, emisiju štetnih gasova itd. Sa uvođenjem novih

${ }^{10} \mathrm{Ibid}$. 
„evropskih" poreza, nadnacionalni nivo će sebi prokrčiti put u domen poreske politike, nekadašnju nedodirljivu sferu autonomije država članica.

Nakon što su do 31. maja 2021. godine sve države članice ratifikovale Odluku o sopstvenim resursima u skladu sa ustavnim zahtevima, Komisija je mogla da počne da se zadužuje. Ona je 15. juna, u svojoj prvoj transakciji o okviru programa „Nova generacija EU“ prikupila 20 milijardi evra putem desetogodišnje obveznice, kako bi finansirala oporavak država Unije od posledica pandemije. Radi se o najvećem izdavanju institucionalnih obveznica u Evropi, odnosno najvećem iznosu koji je EU prikupila u jednoj transakciji. Tim povodom predsednica Komisije istakla je da je reč o istorijskom danu za EU, te da „kao jaka Unija, zajedno prikupljamo novac na tržištima i ulažemo u zajednički oporavak od krize“. Navela je da je to "ulaganje u budućnost sledećih generacija u Evropi, koje će se suočiti sa izazovima digitalizacije i klimatskih promena". ${ }^{11}$

Da bi dobila sredstva, svaka članica mora da precizira kako će potrošiti novac iz tzv. mehnizma za oporavak i otpornost (engl. Recovery and Resilience Facility). Portugal je prva država kojoj je Komisija odobrila plan trošenja sredstava za oporavak.

Uvođenje naddržavnog ekonomskog instrumenta za oporavak nakon pandemije je u polju evropskih studija otvorilo intenzivne rasprave u pogledu njegovih dometa i budućnosti EU. Pojedini autori u novom evropskom fondu vide jasne znake transformacije Ekonomske i monetarne unije u smeru ka evropskoj fiskalnoj uniji i indirektnom uvođenju fiskalnog federalizma. Okolnost da će se deo fonda za oporavak od pandemije finansirati putem dugoročnih obveznica čiji je garant Komisija, mnogi evrofili su pozdravili kao „Hamiltonov momenat" za EU, gradeći istorijske paralele sa čuvenim političkim kompromisom iz 1790. godine za koji je zaslužan prvi sekretar američkog trezora Aleksandar Hamilton, kojim je omogućeno saveznoj vladi da preuzme dug američkih država, akumuliran tokom rata za nezavisnost, i otplati ga saveznim obveznicama. Aranžman je nepovratno proširio nadležnosti savezne vlade Sjedinjenih Američkih Država i uspostavio fiskalnu uniju. Program "Sledeća generacija EU“ svakako ne uspostavlja trajnu centralizovanu (naddržavnu) fiskalnu uniju evropskih država, ali zato se može pojmiti kao važan integracioni proboj, i zajedno

\footnotetext{
${ }^{11}$ European Commission, "Next Generation EU: European Commission raises $€ 20$ billion in first transaction to support Europe's recovery", Internet: https://ec.europa.eu/commission /presscorner/detail/en/ip_21_2982, 20/06/2021.
} 
sa nestandardnom monetarnom politikom Evropske centralne banke, moguće, i kao prekretnica u oblasti ekonomskog upravljanja još od centralizacije monetarne politike Ugovorom iz Mastrihta.

\section{Debata o „koronaobveznicama"}

Tzv. koronaobveznice su najšire shvaćene kao instrument zajedničkog izdavanja javnog duga u svim državama članicama evrozone. Slični predlozi su iznošeni ranije u pogledu tzv. evroobveznica, u vezi sa krizom evra. Ekonomisti i političari, bez obzira na njihovu ideologiju, načelno podržavaju ovu ideju ako je rasprava akademski transparentna, a analiza uzima u obzir sve preduslove. Ipak, postoji dominantna kakofonija zagovornika i protivnika koji u nekim slučajevima apologetski izostavljaju, ili pak namerno prikrivaju potrebne ekonomske i političke preduslove. ${ }^{12}$

Pre svega, dobro je poznata okolnost da niti EU, niti evrozona, ne tvore državni prostor. Iz Osnivačkog akta to jasno proizilazi. Ne postoji evropski fiskalni suverenitet, pa samim tim ni pravo na izdavanje javnog duga. Štaviše, ne postoji istinski evropski (federalni, odnosno javni) budžet, niti evropski ministar finansija sa ovlašćenjima na nivou država članica. Fiskalna politika, kao i socijalna, radna i zdravstvena politika su u nadležnosti isključivo država članica. Ovo objašnjava razlike u poreskim opterećenjima za pojedine zemlje, starosnu granicu za penzionisanje i nivo ulaganja u zdravstvo ili obrazovanje, ili nivo opštih javnih usluga. Sumarno, navedene razlike odražavaju nacionalne političke sklonosti svake od 27 zemalja članica. ${ }^{13}$

\section{Scenariji razvoja naddržavnog ekonomskog upravljanja}

Rasprave o budućnosti i razvoju EU nikada ne jenjavaju, jer je Unija politička zajednica i sistem koji nije statičan, već naprotiv - podložan je stalnim promenama koje su podstaknute, kako unutrašnjom međudržavnom i

\footnotetext{
12 Bodo Herzog, "Whither Coronabonds? The Past and Future of the EMU in the Coronavirus Pandemic", Intereconomics Review of European Economic Policy, Volume 55, May/June 2020, Number 3, p. 4.

13 lbid.
} 
institucionalnom dinamikom, tako i uticajima iz spoljnog okruženja. Putovanje ka nepoznatoj destinaciji u značenju ugovornog cilja „sve bliže Unije naroda Evrope" postalo je nezaobilazni deo identiteta EU. Scenariji su važan analitički alat kojem istraživači u oblasti evropskih studija rado pribegavaju kako bi „mapirali“ eventualne budućnosti za EU, stavljajući u fokus trenutno preovlađujuće trendove i putanje razvoja. U ovom radu su predstavljena četiri scenarija prvenstveno usmerena na moguće transformacije Ekonomske i monetarne unije a onda i šire - političkog sistema EU.

\section{Nastavak puzajuće integracije u domenu ekonomskog upravljanja}

Ivan Krastev, u delu naslovljenom Posle Evrope, pita se da li treba da nas brine krhkost Evrope ili treba da budemo impresionirani njenom otpornošću. ${ }^{14}$ Umesto što evropske elite pokušavaju da obezbede opstanak EU podižući joj legitimitet, možda bi demonstracija njene sposobnosti da preživi mogla postati veliki izvor njenog budućeg legitimiteta. ${ }^{15}$ Oni koji podržavaju manje ambiciozan i pragmatičan pristup razvoja Unije mogli bi reći da politička snaga Unije nikada nije ni bila u detaljnoj viziji budućnosti (iako istorija pamti mnogo takvih inicijativa, od kojih je većina osuđena da ostane tek "mrtvo slovo na papiru“, ili je pak doživela neuspeh kada je testirana u polju praktične politike), već njena sposobnost da prevaziđe neuspehe i prilagodi se novonastalim okolnostima.

Kako bi ovo „prežiljavanje“ moglo da izgleda u praksi u narednih deset, eventualno petnaest godina? Države članice bi udruženo reagovale na buduće mini-krize i krize kako se pojave, sledeći obrazac od poslednjih nekoliko godina. S obzirom na različite interese i probleme sa kojima se suočavaju različite zemlje u evrozoni i EU, zajedno sa glomaznim upravljačkim strukturama i poteškoćama koje bi zadala promena ugovora, ovo je put kojim se nacionalni lideri najmanje protive, a samim tim i onaj koji će najverovatnije slediti. Nameće se pitanje iznalaženja puta da se krene napred.

Jedan od zaobilaznih puteva za dosezanje „više Evrope“ mogao bi uzeti oblik postepenog povećanja evropskog budžeta i uvođenja novih programa i funkcija, uključujući i postepeno dodavanje novih načina njegovog punjenja. Ipak,

\footnotetext{
${ }^{14}$ Ivan Krastev, Posle Evrope, Samizdat B92, Beograd, 2017, str. 104.

${ }^{15}$ Ibid., str. 105.
} 
dalekosežnija i politički osetljivija rešenja zahtevaju pristanak svih članica. Takođe, i „Evropski zeleni dogovor“ (engl. European Green Deal) je moguće posmatrati u svetlu inkrementalnog razvoja integracije.

\section{Scenario dezintegracije}

Jan Zjelonka (Jan Zielonka) ukazuje na činjenicu da, iako su njegove liberalne kolege artikulisale brojne teorije evropskih integracija, ne postoji nijedna teorija evropske dezintegracije, odnosno raspada Unije. ${ }^{16}$ Bregzit je već srušio jednu od osnovnih, ako ne pretpostavki a onda uverenja na kojima se temelji napredak evropskog projekta: da će se, iako nekad teško i sporo, integracija uvek kretati napred.

Bregzit je veoma važan, jer pruža primer da je jedan od mogućih puteva za prevazilaženje nezadovoljstva naddržavnim upravljanjem davanje glasa narodu putem organizovanja obavezujućeg referenduma. Nakon početnog iznenađenja, koje su izazvali rezultati referenduma 2016. godine, mnogi su usled unutrašnjih političkih nestabilnosti sa kojima se Ujedinjeno Kraljevstvo suočilo u narednim mesecima i godinama, izrazili skepsu da li će do Bregzita uopšte doći. Mogla su se čuti zalaganja kako je potrebno održati još jedan referendum. Dobro je što takva ideja nije realizovana. Bregzit je dao primat nacionalnoj demokratiji sa svim njenim manama (tesna većina koja je presudila ishod referenduma ostavila je veliki deo građana nezadovoljnim), ${ }^{17}$ nad ostankom u aranžmanu za koji su glasači procenili da guši nacionalnu autonomiju i suverenitet naroda, odnosno parlamenta. U narednim godinama imaćemo više uvida da li se Ujedinjeno Kraljevstvo suočilo sa nekom od katastrofalnih političkih posledica na koje su najljući kritičari Bregzita upozoravali. Za sada, deluje da će se britanski lideri „koliko-toliko" uspešno prilagoditi novonastaloj situaciji. Mada, Ujedinjeno Kraljevstvo važilo je za najmanje integrisanu članicu, tako da bi troškovi izlaska shvaćeni u najširem smislu sasvim sigurno bili viši za neku drugu zemlju, naročito one koje pripadaju evrozoni. Na kraju krajeva, Ujedinjeno Kraljevstvo će jednog dana biti slobodno da pod nekom novom proevropskom vladom ponovo zatraži

\footnotetext{
${ }^{16}$ Jan Zielonka, Counter-Revolution: Liberal Europe in Retreat, Oxford: Oxford University Press, 2018, p. 28

${ }^{17}$ Izlazak iz Unije podržalo je 52\% građana, dok se za ostanak izjasnilo $48 \%$ građana Ujedinjenog Kraljevstva.
} 
prijem u Uniju, koliko god u ovom trenutku ta opcija delovala malo verovatnom. Ironično ili ne, ali Velika Britanija je danas sedište jednog od najvećih grassroots pokreta koji podržava Uniju.

Deni Rodrik smatra da u današnjoj Evropi demokratija jedino može biti ponovo osvojena odbranom i dokazivanjem nacionalnog suvereniteta. ${ }^{18}$ Ukoliko koncept suvereniteta razumemo kao pravo država na nezavisno postojanje i autonomiju, onda proizilazi da je najdelotvorniji način za povratak demokratije na prostor današnje Unije, u stvari odustanak od Unije naroda Evrope i povratak na Evropu nacionalnih država. U tom slučaju one bi bile ponovo slobodne da izaberu međunarodne aranžmane i odnose sa subjektima međunarodnih odnosa za koje procene da su im u interesu. Imajući u vidu razorne posledice krize evra po sužavanje nacionalne autonomije u ekonomskom domenu država najteže pogođenih krizom, postavlja se pitanje da li se i za jednu od dotičnih država još uvek može reći da je suverena.

Analitičari su najviše polemisali o eventualnom jednostranom izlasku Grčke iz evrozone (u stvari „izbacivanju“ kao vidu „kazne“ za ugrožavanje finansijske stabilnosti evrozone), zatim Italije (kao posledica odluke vlade da okrene leđa strukturnim reformama koje koče rast), a onda i Nemačke (dovoljno ekonomski snažna da može da prosperira i van zone evra).

Prema Džozefu Stiglicu, Italija je dovoljno velika zemlja, sa dovoljno dobrih i kreativnih ekonomista koji bi uspeli da izvedu de facto odlazak iz zone evra uspostavljajući u stvari fleksibilnu dvostruku valutu koja bi mogla pomoći u obnavljanju prosperiteta. ${ }^{19}$ On odmah dodaje, da bi takav put bio protivan pravilima po kojima funkcioniše evro, ali bi teret de iure odlaska sa svim posledicama bio prebačen sa Rima na Brisel i Frankfurt. Italija bi u tom slučaju računala na paralizu EU koja bi bila suočena sa teškim zadatkom sprečavanja konačnog raskola u zoni evra. ${ }^{20}$ Kakav god da bi bio konačni ishod ovog neizvesnog puta za uključene aktere, evrozona se u svakom slučaju ne bi lako

\footnotetext{
${ }^{18}$ Dani Rodrik, "Greece's Vote for Sovereignty", Project Syndicate, Jul 7, 2015, Internet: https://www.project-syndicate.org/commentary/greece-referendum-nationalismdemocracy-by-dani-rodrik-2015-07, 09/01/2021.

19 Joseph E. Stiglitz, "Can the Euro Be Saved?", Jun 13, 2018, Project Syndicate, Internet: https://www.project-syndicate.org/commentary/next-euro-crisis-italy-by-joseph-estiglitz-2018-06? barrier=accesspaylog, 11/11/2020.

20 Ibid.
} 
oporavila od udarca koji bi prouzrokovao jednostrani odustanak jedne tako važne članice od evra.

Uvođenje nove nacionalne valute bi verovatno bilo praćeno njenom devalvacijom sa kratkoročnim ciljem pospešivanja izvoza, a dugoročnim ciljem podizanja konkurentnosti privrede. Dok npr. Italija ima snažan izvozni sektor, Grčka se većinom oslanja na usluge. S druge strane, vraćanje inostranih kredita postalo bi skuplje, posebno u slučaju država koje su već prezadužene. ${ }^{21}$ Objektivna prepreka na koju se mora računati u slučaju napred razmatranih mogućnosti jeste da izlazak pojedinačne članice iz evrozone nije normiran u osnivačkim aktima.

\section{„Oni koji žele više - čine više}

„Evropa u više brzina“ je pristup integracijama koji već više godina unazad dominira u debatama o reformi EU, ali i koji je, važno je istaći, u mnogim oblastima evropskih javnih politika bio, jeste, i ukoliko je suditi prema trenutnom stanju stvari - biće - realnost njenih unutrašnjih odnosa. Načelna ideja je da se, umesto dogovora o tome kada i kako postići neki optimalni nivo integracije, svakoj zemlji članici EU omogući da napreduje ka željenim ciljevima sopstvenom brzinom. Niz zainteresovanih zemalja pokreće inicijativu, a ostale se mogu pridružiti kada nađu za shodno. Ovaj pristup je normiran u Evropskim ugovorima i poznat je kao postupak bliže ili ubrzane saradnje (čl. 328 Ugovora o funkcionisanju EU). lako priznat, on nikada nije uzdignut do nivoa opšteg principa ili strategije budućeg razvoja Unije. Ono što se na prvi pogled može učiniti kao pogodan način (a nekada možda i nužnost) da se zaobiđe složeni proces pregovaranja ili uslov jednoglasnosti, zapravo krije ozbiljne probleme. U jednom delu teorije se očitava stav da je potrebna zajednička vizija zasnovana na zajedničkim vrednostima, slobodama i standardima ka kojoj treba da streme sve njene članice, kako bi Unija odista napredovala.

\footnotetext{
${ }^{21}$ Milenko Dželetović, Ljubomir Šubara, Evro i monetarna integracija Evrope, Institut za međunarodnu politiku i privredu, Beograd, 2017, str. 378.

22 Jedna od strategija u „Beloj knjizi o budućnosti Evrope“ nosi naziv „oni koji žele više čine više".
} 


\section{Da li je ideja o Sjedinjenim Državama Evrope tek „sanak pusti" evrofederalista?}

Ideja o političkom ujedinjenju Evrope vekovima je bila zastupana od strane širokog kruga evropske intelektualne elite. Obraćajući se studentima u Cirihu 1946, britanski premijer Vinston Čerčil predložio je stvaranje Sjedinjenih Evropskih Država. Ovaj čuveni govor u kome su naznačeni neki od najvažnijih gradivnih elemenata buduće evropske Zajednice/Unije, predstavlja neizostavni momenat istorije evropske integracije. ${ }^{23}$

U pogledu institucija, evropski federalisti veruju da bi u federalnoj političkoj uniji vlast trebalo rasporediti na sledeći način:

1) Evropska komisija treba da postane evropska vlada, sa ekskluzivitetom izvršne vlasti. Njen predsednik i komesari trebalo bi da odražavaju političku većinu u Evropskom parlamentu.

2) Evropski parlament treba da ima jednaka zakonodavna ovlašćenja kao i Savet ministra. Njegov panevropski legitimitet trebalo bi ojačati izborom značajnog broja poslanika sa panevropskih lista.

3) Evropski savet, u kojem zasedaju šefovi država i vlada, trebalo bi da prepusti Evropskoj komisiji sva preostala izvršna ovlašćenja i vrati se ulozi postavljanja dugoročne političke agende i osiguranja opšteg nadzora nad politikom. Sve svoje odluke treba da donosi većinom ili kvalifikovanom većinom u kritičnim oblastima.

4) Ustav treba da zameni trenutne međunarodne ugovore i predvidi da može biti izmenjen i dopunjen sporazumom većine u Evropskom parlamentu, Evropskom savetu i državama članicama. ${ }^{24}$

Svojevremeno, nakon pobede Emanuela Makrona na predsedničkim izborima u Francuskoj, kao i uspeha njegovog pokreta na izborima za Evropski parlament, na talasu optimizma po pitanju budućnosti evropskog projekta pojedini komentatori su otišli tako daleko da su tvrdili da Makron iskonski veruje da se suverenitet u današnjoj Evropi jedino može ostvariti na nivou EU, te da će

\footnotetext{
${ }^{23}$ Videti: Winston Churchill, "United States of Europe", September 19, 1946. University of Zurich, Internet: https://winstonchurchill.org/resources/speeches/1946-1963-elderstatesman/united-states-of-europe/, 19/03/2021.

${ }^{24}$ The Union of European Federalists, "Federal Political Union", Internet: https:// www.federalists.eu/uef/manifesto/federal-political-union, 09/03/2021.
} 
upravo on Francusku povesti iz Pete republike u Šestu republiku koja više nije strogo frankocentrična, već odista evropska. ${ }^{25}$ Kako je ispunjen uslov vremenske distance (tri godine je prošlo od njegovog stupanja na dužnost), zapitajmo se na ovom mestu, da li je Makron opravdao makar deo nada koje su u njega polagali evrofederalisti. ${ }^{26}$

Važno je istaći da sadašnji francuski predsednik nije osvojio predsedničke izbore na način na koji se holandski premijer Mark Rute (Mark Rutte) održao na vlasti (prisvajajući razvodnjene i/ili prikrivene poruke stranaka protiv kojih se borio), već stavljajući u prvi plan pozitivnu proevropsku integracionu platformu. On je, kako tokom predsedničke kampanje tako i u kasnijim govorima i autorskim tekstovma, izložio ambicioznu ideju da se učini veliki skok napred u integraciji ka evropskoj fiskalnoj uniji. Njene glavne komponente bile bi zajednički budžet koji bi se jednim delom finansirao porezom na finansijske transakcije širom EU (trenutno samo Francuska i Ujedinjeno Kraljevstvo naplaćuju takav vid poreza), imenovanje evropskog ministra finansija, kao i mere za usklađivanje korporativnog poreza i minimalnih zarada u državama članicama. To bi, prema njegovom viđenju, omogućilo trajne fiskalne transfere iz jačih zemalja u zemlje koje su u nepovoljnijem položaju, nekada čak i zbog jedinstvene monetarne politike koja ne može istovremeno biti po meri svih članica. Budžet evrozone finansirao bi se najvećim delom doprinosima iz poreskih prihoda evropskih država. Zasebni parlament evrozone obezbedio bi politički nadzor i odgovornost. Mnogo stvari je ostalo nedorečeno - na primer, kako bi ministar finansija evrozone bio pozvan na odgovornost i kako bi bila osigurana demokratska legitimnost njegovog položaja, a nije mnogo rečeno ni o njegovom odnosu sa postojećim evropskim institucijama (npr. da li bi potekao iz redova komesara ili ministara finansija, da li bi odgovarao državama članicama ili Evropskom parlamentu, ili možda novom parlamentu evrozone čije se osnivanje takođe predlaže).

\footnotetext{
${ }^{25}$ Mark Leonard, "Macron Takes Aim at European Politics", Project Syndicate, Mar 27, 2018, Internet: https://www.project-syndicate.org/commentary/macron-2019-europeanparliament-election-by-mark-leonard-2018-03?barrier=accesspaylog, 23/11/2020.

${ }^{26}$ Otežavajuća okolnost za procenu učinka državnika predstavlja globalna pandemija koja je svima nametnula suočavanje sa izazvovima koje nisu mogli da predvide. Detaljnije o Makronovoj politici videti u: Nevena Stanković, "Glavne odrednice spoljne politike Emanuela Makrona“, Međunarodna politika, god. LXXI, br. 1179-80, jul-decembar 2020, str. 65-95.
} 
Nalazimo da je glavni problem, odnosno ključna slabost Makronove vizije za EU 21. veka, upravo ono što se u pojedinim komentarima označava kao njena snaga. Naime, čini se da Makronova vizija Evrope nastoji da pomiri nepomirljivo. ${ }^{27}$ Njegov plan je istovremeno očuvanje suvereniteta država članica, uz produbljivanje evropske integracije. $U$ institucionalnom smislu to znači podržavanje nadnacionalnih tela, uz istovremeno omogućavanje veće fleksibilnosti u oblastima u kojima su nacionalne vlade, a ne Brisel, bolje pozicionirane da rešavaju probleme. ${ }^{28}$ Makronovi predlozi su suviše brojni i nedovoljno precizni pa nije nimalo lako usvojiti sud o njima. ${ }^{29}$ Takođe, oni ne vode dovoljno računa o političkim prioritetima i raspravama na nacionalnom nivou država članica, gde je evroskepticizam, ako ne više u porastu (ako je suditi prema rezultatima poslednjih izbora za Evropski parlament), onda legitimna politička opcija koja se mora imati u vidu kada se kuju planovi za zajedničku evropsku budućnost. Ono što se sada već sa velikom dozom sigurnosti može tvrditi jeste da uprkos ambicioznoj proevropskoj agendi, Emanuel Makron nije državnik koji će približiti realnosti snove evrofederalista o „Sjedinjenim Državama Evrope“.

\section{Ključni izazovi sa kojima će se Unija suočiti u narednom periodu}

Bez obzira na njene široko opažene i raspravljane slabosti, EU predstavlja nezanemarljiv globalni subjekt. $U$ ekonomskom smislu, nezaobilazan je faktor

\footnotetext{
${ }^{27}$ Govorilo se o "Makronovom metodu“ koji bi trebalo da predstavlja „treći put" u polju evropskog sporazumevanja i od koga se očekivalo da prebrodi sile populizma i tehnokratije koje dominiraju današnjom Unijom. Kako bi „,velike pogodbe“ i politički kompromisi putem kojih očekuje da zakomeša ustajalu vodu evropske politike zaživele, moraće da se suoči sa nimalo lakim zadatkom premošćavanja geografskih podela unutar EU, biće prinuđen da se pozicionira istovremeno kao proevropski i patriotski državnik, čovek iz establišmenta, koji je istovremeno i njegov protivnik, onaj koji je za otvorenu ekonomiju, ali i shvata da je protekcionizam nekada jedino rešenje, fiskalno suzdržan ali koji promoviše rast. Detaljnije u: Mark Leonard, "The Macron Method", Project Syndicate, May 29, 2017, Internet: https://www.project-syndicate.org/commentary/macron-project-to-unite-europe-bymark-leonard-2017-05?barrier=accesspaylog, 10/04/2021.

${ }^{28}$ Mark Leonard, "Macron Takes Aim at European Politics", op. cit.

${ }^{29} \mathrm{U}$ predmetnom radu pažnja je posvećena njegovim predlozima u ekonomskom domenu. Između ostalog, on je predložio i zajednički evropski fond za odbranu, kao i listu kandidata za Evropski parlament na nivou EU.
} 
globalnog razvoja, a u političkom smislu redovan je učesnik svih međunarodnih političkih procesa. Ono što se postavlja kao pitanje je stabilnost, pa čak i održivost razvoja EU u smislu njenog sve većeg učešća u globalnim procesima. Tu se prevashodno govori o njenoj upitnoj snazi da bude odlučujući faktor.

Jedan od problema sa kojima se EU suočava, povezano sa globalnim procesima, jeste jačanje finansijskih subjekata koji njen složeni sistem upravljanja destabilizuju iznutra. Radi se o promenama na finansijskom i monetarnom planu koje direktno utiču na život evropskih građana. Ove promene uzrokuju postepenu, ali sigurnu polarizaciju u životnom standardu i kvalitetu života. Time se izaziva unutrašnja nestabilnost EU, čime se slabe osnovni kapaciteti njenog razvoja. Posledično, EU slabi na spoljnom planu jer se istovremeno na globalnom planu pojavljuju novi uticajni akteri.

Sjedinjene Američke Države su stari takmac EU kada se radi o globalnoj političkoj i ekonomskoj moći, ali sada se kao izraziti konkurent pojavljuje i Kina kao subjekt sa naizgled nezasitim globalnim ambicijama. Do sada se kineski način u sticanju globalnog uticaja pokazao efikasnim. Kina je čak uspela da uđe i u zonu evropskog uticaja, kao što je region Zapadnog Balkana. Bez obzira na to, EU ne može primeniti kineske principe, već je potrebno da pronađe nove načine za sticanje većeg uticaja na globalnom planu.

EU ima mogućnost da se takmiči sa Kinom na planu „meke moći“, ali će bez razvoja sopstvenih vojnih kapaciteta izgubiti mogućnost da preuzme aktivniju globalnu ulogu. S druge strane, pitanje je da li bi EU uopšte trebala da ide u tom pravcu. U slučaju razvoja autonomnih vojnih kapaciteta EU mora računati da će biti uključena u konflikte u svetu, što podrazumeva da će morati da izabere "stranu". Shodno tome, nije isključena mogućnost da EU iSAD u jednom trenutku budu na suprotnim stranama kada se radi o rešenju nekog međunarodnog problema. Još uvek su sveža sećanja na iračku spoljnopolitičku krizu. Dalje, ono što SAD i Kinu izdvaja u odnosu na EU, i daje im prednost na globalnom planu jesu inovacije. Ove dve globalne sile ubrzano se razvijaju u mnogim oblastima, na primer, digitalnim tehnologijama, što im donosi velike profite i veći uticaj u svetu. U tome posebne napore ulaže Kina koja bi želela da postane dominantan faktor u oblasti inovacija. Ne treba zaboraviti ni Rusiju. Ova država je prošla dug period ponovnog uspostavljanja stabilnosti na globalnom planu od raspada Varšavskog pakta. I Rusija je, poput Kine, ušla na teren EU u oblasti Zapadnog Balkana, prevashodno oslanjajući se na sirovine poput nafte i gasa. 
EU se još uvek bori za unutrašnju ekonomsku stabilizaciju koja je ozbiljno narušena finansijskom krizom iz 2008. i krizom javnih dugova u evrozoni koja je usledila. Određeni finansijski subjekti, poput banaka ili fondova, dovoljno su ojačali da poljuljaju finansijsku stabilnosti evrozone. Dobar deo problema u vezi sa ekonomskom održivošću ekonomskog sistema EU proističe iz globalnih ekonomskih tokova koji su se prelili na njeno tle. Drugi deo problema vezuje se za manjkavosti nadnacionalnih institucija ekonomskog upravljanja. Problemi se uočavaju na nivou ekonomskog sistema EU, odnosno ekonomskih sistema njenih država članica. To je i logično s obzirom na to da su ekonomski i finansijski subjekti međusobno povezani u današnjem globalizovanom svetu.

Privrženost evropskih građana ideji o „sve bližoj Uniji naroda Evrope“, jedan je od kamena temeljaca njenog opstanka i daljeg razvoja. Zato je važno da evropski zvaničnici obrate pažnju na kvalitet života građana Unije. Mnoge sile nisu sprečile raslojavanje među svojim građanima, jer omogućavaju oporezivanje koje favorizuje akumulaciju i održavanje bogatstva među najbogatijim građanima. Ipak, unutrašnja organizacija EU i premise njenog osnivanja nisu bile takve, a nisu ni danas. Postavlja se pitanje na koji način EU može da opstane da dosadašnjim premisama, a da dodatno razvije svoju globalnu moć. U tom smislu, za EU je od najveće važnosti da pronađe održiva rešenja za pitanja ekonomske stabilnosti i napretka na duži rok.

\section{Zaključak}

Čitav svet, pa onda i Evropska unija kao dosad najuspešniji ekonomski i politički eksperiment regionalnog povezivanja suverenih država, nalazi se u stanju previranja. Pandemija virusa Kovid 19 na videlo je iznela krhkost globalnih procesa koje smo počeli da uzimamo kao datost. Globalna umreženost, globalni sistemi upravljanja i lanci snabdevanja, međunarodna povezanost i mobilnost još uvek nisu dostigli pretkrizni nivo. $U$ akademskoj zajednici i šire uveliko se raspravlja o tome kako će svet izgledati u narednim godinama i decenijama. Raspravi o postpandemijskoj eri moguće je pristupiti iz više uglova, odnosno analizirati različite izazove kao zdravstvene, bezbednosne, ekonomske, političke, ekološke itd. Predmetni rad je imao za cilj da ponudi viđenje budućih pravaca političkog i ekonomskog razvoja koje EU ima na raspolaganju, kao i prepreke sa kojima bi se mogla suočiti. 
Sve su jači glasovi onih koji se zalažu za uspostavljanje fiskalnog kapaciteta na nivou evrozone, ili, jednostavnim rečima - budžeta evrozone, uključujući mogućnost zaduživanja pod pretpostavkom kolektivne odgovornosti. Uprkos snažnim argumentima ekonomista da je ovakav razvoj poželjan, previše je spornih tačaka i naizgled nepremostivih političkih prepreka. Postavlja se pitanje kako obezbediti prihodovnu stranu, ili kako ubediti jake ekonomije da je zajednički dug i fiskalni federalizam dobra ideja. Trenutno se ni ne nazire upravljačka struktura koja bi bila zadužena za izvršenje istinskog nadnacionalnog budžeta, ili makar ne ona koja bi uživala demokratski legitimitet.

Dogovor o političkoj uniji zasnovanoj na demokratskim osnovama je preduslov dublje ekonomske integracije. Problem je u tome što su evropske elite toliko navikle da se provlače kroz iglene uši političkih pogodbi i sila ekonomske nužnosti da dugoročna rešenja, koja bi garantovala legitimnost zajedničkih odluka, u trenutnim okolnostima deluju gotovo bez izgleda.

\section{Literatura}

Dabić, Dragana, Gajić, Branimir, „Evropska bankarska unija kao deo postkriznog sistema upravljanja Ekonomskom i monetarnom unijom", Evropsko zakonodavstvo, 73-74/2020.

Dželetović, Milenko, Šubara, Ljubomir, Evro i monetarna integracija Evrope, Institut za međunarodnu politiku i privredu, Beograd, 2017.

Herzog, Bodo, "Whither Coronabonds? The Past and Future of the EMU in the Coronavirus Pandemic", Intereconomics Review of European Economic Policy, Volume 55, May/June 2020, Number 3.

Krastev, Ivan, Posle Evrope, Samizdat B92, Beograd, 2017.

Stanković, Nevena, "Glavne odrednice spoljne politike Emanuela Makrona“, Međunarodna politika, god. LXXI, br. 1179-80, jul-decembar 2020.

Zielonka, Jan, Counter-Revolution: Liberal Europe in Retreat, Oxford: Oxford University Press, 2018. 
Razvojni pravci Evropske unije nakon pandemije Kovid 19

\title{
FUTURE DEVELOPMENTS OF THE ECONOMIC AND POLITICAL SYSTEM OF THE EUROPEAN UNION AFTER THE COVID-19 PANDEMIC
}

\begin{abstract}
The White Paper on the Future of Europe, published by the European Commission in 2017, outlines five possible directions forward for the European Union- from narrowing the focus on the single market to deepening and expanding integration to new public policies and areas of governance. It also includes a proposal for a "multi-speed Europe", for which, nowadays, with great certainty, it can be argued that it represents not only the past and present of integration processes, but their future as well. The White Paper does not take into account the basic issue of regulating the future order, and that is how to divide power within the EU. In this aspect, the Union does not have five possibilities, but two: supranational and intergovernmental. The approach chosen will shape the structure of the Union and the scope of its activities. For a while, it seemed that the time for the redesign of the Economic and Monetary Union had passed and that the Eurozone would have to function with the architecture inherited from its crisis years. A new European fund to help members hardest hit by the COVID-19 pandemic, called the Next Generation EU, which introduces limited joint responsibility for a debt under the assumption of European solidarity, shows that this is no longer the case. Different views of the development of the European unification project can be found in the literature. Most studies are limited to broad settings, depending on the author's views on what is necessary or possible. Within the framework of four separate scenarios of long-term development of the EU, the possible sub-scenarios will be presented. The emphasis is on the most closely integrated group of member states sharing a common currency. The paper argues that only a political decision can restore the stability of the system and re-establish a clear vertical division of competencies, and thus also ensure the legitimacy of the governance of European economies. The political decisions of the member states should be based on the will of European citizens and can lead either to building a political union with a supranational fiscal union as its integral part or to renouncing the euro.
\end{abstract}

Keywords: Economic and monetary union, Eurozone, euro crisis, pandemic, supranational governance, fiscal union, political union, Brexit. 